\title{
Role of Landscape Designers in Promoting a Balanced Approach to Green Infrastructure
}

\author{
Christina A. Breed ${ }^{1}$, Sarel S. Cilliers ${ }^{2}$, and Roger C. Fisher ${ }^{3}$
}

\footnotetext{
${ }^{1}$ Lecturer in Landscape Architecture, Department of Architecture, Faculty of Engineering, Built Environment and Information Technology, University of Pretoria, Pretoria 0002, South Africa (corresponding author). Email: ida.breed@up.ac.za

${ }^{2}$ Professor in Plant Ecology, School of Biological Sciences, Faculty of Natural Sciences, North-West University, Main Campus, Potchefstroom 2531, South Africa, E-mail: sarel.cilliers@ nwu.ac.za.

${ }^{3}$ Professor in Architecture, Department of Architecture, Faculty of Engineering, Built Environment and Information Technology, University of Pretoria, Pretoria 0002, South Africa, E-mail: roger.fisher@up.ac.za.
}

\begin{abstract}
The importance accorded to green infrastructure is related to socio-cultural values, which also affect the social production of ecosystem services. The literature distinguishes four categories of ecosystem services to be included in green infrastructure, namely cultural, regulating, provisioning and supporting services. This study considers the current role of landscape design practice in South Africa in the social production process by analyzing design projects featured in three prominent profession-focused magazines over nine years, since 2004. The magazine analysis indicates that, contrary to what the scientific literature and theory propounds, landscape design practitioners perceive cultural and regulating services as more important than provisioning or supporting services. This is evident from recurrent discussions in these magazines focusing on aspects such as social and community matters, sustainability, and the showcasing of design and aesthetics. The analysis also suggests that environmental law, ratings systems, and award systems influence what landscape design practitioners consider important. It is suggested that award systems are best positioned to re-orient values and promote a well-balanced inclusion of ecosystem services in green infrastructure.
\end{abstract}

CE Database subject headings: South Africa, urban development, land use, landscaping, ecosystems, social factors, sustainable development, design. 
Author keywords: green infrastructure, ecosystem services, socio-cultural values, landscape designers.

\section{Introduction}

Willingness to protect biodiversity and the effectiveness of such protection is related to both socio-economic realities and socio-cultural values (MEA 2005). In South Africa, a significant location in respect of global biodiversity (Myers et al. 2000), threats to biodiversity posed by urbanization (Lindenmayer and Fischer 2006) tend to be overshadowed by socio-economic challenges, such as increasing poverty and high levels of social inequality (UN-Habitat 2010). As a result, the need to provide basic infrastructure is perceived to outweigh the need to protect or enhance green infrastructure by far (Cilliers 2010b), even though such green infrastructure would support a biodiversity that could provide important ecosystem services (Colding 2011; Gómez-Baggethun and Barton 2013), and could be a valuable strategy to combat social inequity, reduce ecological footprints, provide social goods and increase resilience (Gómez et al. 2011; Young 2011).

The provision of infrastructure is not regarded as an ecosystem service, but the forms of capital required to produce it depend on natural goods and services (McMichael and Scholes 2005:47). The term ecosystem services refers to the benefits nature supplies that enhance human well-being (TEEB 2011). Since ecosystem services are often not adequately valued (or priced), there is a risk that they will be mismanaged (Colding 2011). Hence, there have been increasing attempts to incorporate the concept in government planning and policy to acknowledge the importance of cultural, regulating, provisioning and supporting services in decision-making (TEEB 2011). The suggested adaptive urban planning and management processes are not cheap alternatives but are "more cost-effective, more adaptable and have 
multiple co-benefits across a range of scenarios and time lines" (Roberts et al. 2011:190). In respect of both green infrastructure and ecosystem services, there is a lack of development regarding practice-oriented application frameworks, but a synthesis of these concepts seems promising, especially regarding multifunctionality and an integration of social and ecological systems (Ahern et al. 2014; Hansen and Pauleit 2014).

Green infrastructure is a concept that originated in the United States in the 1990's (Pauleit et al. 2011), and has been defined as "an interconnected network of green spaces that conserves natural ecosystem values and functions and provides associated benefits to human populations" (Benedict and McMahon 2001-5:5). Urban green space has now been internationally recognized to provide "green infrastructure" (Farinha-Marques et al. 2011), which is also defined as "strategically planned" or "high quality green spaces" (Natural England in Douglas et al. 2011:xxi). These terms refer to green infrastructure that considers multifunctionality, the influence and integration of adjacent areas on the quality and use of green habitats (Pauleit et al. 2011), and systems thinking (Hostetler et al. 2011) - connections and interactions between fragmented patches that have high importance for the generation of ecosystem services (Bodin and Norberg 2007), including species dispersal, metapopulation dynamics, access for recreational use and the mitigation of the heat island effect (Pauleit et al. 2011). The concept of green infrastructure therefore includes the entire working landscape, ranging from any remaining natural areas inside a city, parks, remnant vegetation, residential and street vegetation, plus innovative engineered systems, such as green roofs and walls (GIW 2013).

In South Africa, as in England, green infrastructure has come to be considered as a potentially "corruptible concept", swayed by political and personal agendas due to its ambiguity and a lack of general consensus (Wright 2011:1003). In South Africa "high 
quality" has been strongly associated with engineered systems that mimic grey infrastructure utility services. This approach has led to a largely technologically driven focus on the sustainability of cities. Initiatives are mostly technically challenging, resource-intensive and marketing-aimed. This approach has a causal power associated with elite endorsement (see Wilson 1994), and in practice has not been well linked with biodiversity conservation and multifunctionality, compared to examples in other parts of the world (e.g. Douglas and Sadler 2011; Francis and Lorimer 2011; Hostetler et al. 2011). Instead, in South Africa, it has led to the adoption of green rating systems (Green Star; LEED) that are mainly focused on efficient energy consumption management, and are often tied to economic incentives. A rating tool for the landscape design industry has been developed that incorporates all four categories of ecosystem services (the Sustainable Sites Initiative), but, thus far in South Africa, it is not actively employed and the landscape design industry is not proactively leading green infrastructure initiatives. Rating systems tend to emphasize quantifiable aspects that often encourage cost-minimizing behavior, which influences short-term financial decision-making (see Pretty 2003), but has thus far failed to effect long-term changes in social norms and values.

The authors argue that, in South Africa, the way green infrastructure is approached at present is based on a combination of socio-economic realities and socio-cultural values, which exacerbates the failure to regard green assets as having equal importance to grey infrastructure (Schäffler and Swilling 2012). The current approach to green infrastructure does not address the measuring of performance in private and public decision-making based on short-term socio-economic gain (Le Maitre et al. 2007). Furthermore, it does not promote the inclusion of biodiversity and ecosystem services in green infrastructure planning. In the authors' opinion, two major components are currently lacking: firstly, a socially inclusive communicative approach that allows decision-makers, designers and the public to weigh up 
the benefits and losses of various land use scenarios and, secondly, a long-term vision approach that allows for new inputs and does not allow the short-term economic gains of some interest groups to override public best practice and to cause ecosystem service erosion, as described by Pauleit et al. (2011:275).

In order to improve the state of green infrastructure in South Africa to provide more ecosystem services, the authors argue that social norms and values need to be operationalized. This study therefore explores possible reasons for the failure to value green infrastructure in this region by reviewing recent research in the field. The authors believe that landscape designers should fulfill a crucial role in promoting green infrastructure and its ecosystem services. The study accordingly explores the part landscape designers currently play in the articulation of values relating to this concept. This paper aims to establish, first, which concerns are currently important, by analyzing design projects featured in three prominent profession-focused magazines over nine years, second, what these projects reveal about current perceptions in the industry on ecosystem services, and third, how all ecosystem services can become a social priority for green infrastructure design. Finally, the study proposes the use of social practices within the profession that could influence the value that is attributed and the consideration given to green infrastructure in order to re-orient social norms and values.

\section{Review of prior research on green infrastructure}

Research findings are critical for the effective design and implementation of green infrastructure in future urban development (MEA 2005). In South Africa, related research fields include urban ecology (Cilliers and Siebert 2012; Holmes et al. 2012), sustainability science (Le Maitre et al. 2007), infrastructure transition for increased urban resilience (Schäffler and Swilling 2012) and ecosystem services research (Cilliers et al. 2012; De Wit et 
al. 2012; O'Farrell et al. 2012). These fields have a common focus on complex socialecological systems, seeking practical applications for planning and design (Cilliers 2010b) by emphasizing resilience through learning and adaptation (Le Maitre et al. 2007).

Several local studies raising awareness of the services that urban green infrastructure provides have been conducted on a variety of green spaces (e.g. Cilliers and Bredenkamp 2000; Lubbe et al. 2011; McConnachie and Shackleton 2010; Rebelo et al. 2011, also see Cilliers and Siebert 2012 for a reflection on urban ecological studies in South Africa). These isolated studies cover nearly the full spectrum of green infrastructure. However, such studies need to become part of public and professional awareness, in the sense that their results are taken into account in decision-making (Schäffler and Swilling 2012).

The confirmed economic value of ecosystem services provides another rationale for investing in green infrastructure (Mertz et al. 2007; Schäffler and Swilling 2012). Greening efforts are a potential economic driver of property values and investments (Cilliers 2010a; Ernstson et al. 2010). Recent valuation studies in South Africa have focused on specific municipalities (De Wit et al. 2012; Roberts et al. 2005; Stoffberg et al. 2010). Such studies explicitly demonstrate the functions of nature to decision-makers, and they indicate the limitations of monetary measures of the intrinsic and non-exploitive value of nature (Chiesura and Martinez-Alier 2011:94). However, it is difficult to calculate trade-offs or make comparisons between quality of life and economic concerns (Ernstson and Sörlin 2013:276). The act of quantifying the value of such services alone is not enough to function as an incentive to make accountable choices that affect the use or misuse of these services (McMichael and Scholes 2005:55).

The outcome of land use practices depends on the ability and skill of different stakeholders to articulate their concerns to affect decisions (Ernstson 2012). Another research focus to 
improve decisions concerning green infrastructure is therefore to investigate management practices and stakeholder opinions (Le Maitre et al. 2007; Schäffler and Swilling 2012). Some research in South Africa considers the effects of stakeholder perceptions and the outcomes of management practices (e.g. Cilliers et al. 2012; Ernstson 2012; Holmes et al. 2012; McConnachie and Cowling 2013; Urgenson et al. 2013). However, these studies do not include questions of built environment design. Hence, a hitherto unexplored stakeholder group in South Africa is built environment design professionals.

Authors internationally are exploring ways of operationalizing built environment design processes to improve sustainability and resilience e.g. Ahern 212; Ahern et al. 2014; Hansen and Pauleit 2014. Design expresses cultural norms and social institutions in the form of goals, values, interest and outcomes (Swaffield 2013:1194). A number of studies capture public attitudes and preferences regarding qualities or features of nature and urban green space to guide design and management decisions (Alessa et al. 2008; Delavari-Edalat and Abdi 2010; Shwartz et al. 2013; Voigt et al. 2014; Zhao et al. 2013). Some studies also relate these preferences to ecosystem services (e.g. Plieninger et al. 2012, 2013; Van Riper et al. 2012). In most studies "social preferences" (likes or dislikes) are not distinguished from underlying "value orientations" (Ives and Kendal 2014). Preferences held in respect of nature are also seemingly regarded as constant, overlooking cultural norms as interplays of permanencies and processes of change (Box 2011; Clucas and Marzluff, 2011:140). By contrast, Ernstson (2013) applies constructionist theory to reveal social production processes that affect perceptions and behavior in the form of land use decisions. This paper elaborates on these processes in the next section.

Recent studies that acknowledge the professional opinions of researchers and practitioners include those of Hansen and Pauleit 2014; Kirnbauer and Baetz 2014; Young 2011; Yu et al. 
2011. These studies consider knowledge and experience regarding processes, rather than underlying values of professionals. A study by Thomson (1999) investigates professional values in Landscape Architecture in Britain and used literature and interviews with practitioners to unravel sources of "positive values" in the profession. He found three value systems, namely, aesthetics, social and ecological considerations. The relationship between aesthetics and ecology, mediated by human agency, was investigated to discern the role the profession should play in the future of the earth. Thompson (1999) proposes a value framework for the critical appraisal of works in the profession, and admits to the normative force that this framework may hold.

In this study the authors regard current scientific literature on urban ecology as a measure of good practice in terms of social-ecological systems resilience focusing on urban biodiversity conservation. This study used the ecosystem service approach as a conceptual tool, because it allows the built environment to be looked at as "reconstructed nature" and as a product of human intentionality (Pinceti 2012:S36). In line with Thompson (1999), the study proposes the development of a framework for critical appraisal, but the authors go further by identifying social practices and processes that hold potential for a value reorientation. Thus the authors argue that landscape design practitioners should be considered stakeholders capable of effectively articulating concerns relating to land use practices.

Since there are only a small group of qualified landscape architects in South Africa, this study applies the term "landscape design practitioners" to groups and parties dedicated to making decisions around the design and implementation of green space, such as horticulturalists and landscape managers. The power held by landscape designers in their decision-making is explored in the next section. 


\section{The social production of ecosystem services by landscape design practitioners}

\section{Resilience in social-ecological systems}

Urban ecosystems depend to some extent on tangible products from local ecosystems, which has led to a range of choices on how to use land (MEA 2005). The ability to influence land use decisions is a vital economic development tool, as land use plays an important role in the desirability and productivity of a city (Cilliers 2010a). Since land is limited, this implies that spatial patterns of urban ecosystems are strongly influenced and are ultimately determined by political land use struggles (Ernstson 2013). In this way, social practices moderate the quantity and quality of green infrastructure through urban development (Ernstson 2013). This is recognized in the concept of resilience of social ecological systems through the need to manage change (Folke 2006). Folke et al. (2010:n.p.) describe resilience as "the capacity of a system to absorb disturbance and re-organize while undergoing change so as to still retain essentially the same function, structure and feedback".

The Millennium Ecosystem Assessment (MEA 2005:210) portrays social-ecological systems as consisting of three levels of interaction, namely, first, social norms and rules, second, management, actors and organizations, and, third, ecosystem function and dynamics, all of which produce and respond to knowledge systems. The role that actors (such as landscape design practitioners) play in ensuring systems resilience lies in their capacity to manage the required change in the generation of ecosystem services. Actors are influenced socially by the norms, values and knowledge systems which impinge on decision-making. In their turn, many changes in values evolve from broad social or economic trends, which include increased education (Aaron et al. 1994). 
The MEA (2005) has identified five indirect and seven direct drivers of change (see Fig. 1).

Direct drivers have an immediate influence on ecosystems, whereas indirect drivers operate

\begin{tabular}{|c|c|}
\hline Indirect drivers of change & Direct drivers of change \\
\hline $\begin{array}{l}\text { 1. Demographic } \\
\text { 2. Economic (e.g. globalization, trade, market and policy } \\
\text { framework) } \\
\text { 3. Socio-political (e.g. governance, institutional and legal } \\
\text { framework) } \\
\text { 4. Science and technology } \\
\text { 5. Cultural and religious (e.g. beliefs, consumption choices) }\end{array}$ & $\begin{array}{l}\text { 1. Changes in land use and cover } \\
\text { 2. Species introduction or removal } \\
\text { 3. Technology adaptation and use } \\
\text { 4. External inputs (e.g. fertilizer use, pest control, irrigation) } \\
\text { 5. Harvest and resource consumption } \\
\text { 6. Climate change } \\
\text { 7. Natural, physical and biological drivers (e.g. evolution, } \\
\text { volcanoes) }\end{array}$ \\
\hline
\end{tabular}

Fig. 1 Direct and indirect drivers of change for ecosystems that in return affect human well-being (MEA 2005:20).

Source: From Ecosystems and Human Well-Being: Multiscale Assessments by Millennium Ecosystem Assessment. Copyright (C 2005 by MEA. Reproduced by permission of Island Press, Washington, DC.

across broad spectrums and are more difficult to identify and measure (MEA 2005). No individual decision-maker has control over all drivers (MEA 2005). Landscape design practitioners have the power to influence the first four direct drivers of change (see Fig. 1) in everyday landscape projects across a nation. Their professional role is to make recommendations to a client (the State or a private) on decisions to be taken that greatly influence land cover and sense of place, which are seen as key integrators of social and ecological systems (Zipperer et al. 2011).

\section{Social structures and actor networks}

Individuals and small groups have been proven to have the potential to initiate and manage change by means of decision-making (Folke 2006), based on access to information and 
resources, control over land, and political power (Swan et al. 2011). Knowledge regarding decision-making has two dimensions - one entails the status quo, e.g. ecological information; the second relates to external social structures and how to influence them via social knowledge (Zipperer et al. 2011:307). The authors of this study believe that landscape designers are well positioned by their knowledge to influence decision-making and social structures.

Ernstson and Sörlin (2009) have shown that actors with great social network centrality have higher potential to be active in putting together social networks. Accordingly, this study proposes that a network position that allows contact with diverse role players (Ernstson 2013) such as developers, the State, the public, plant growers, built environment professionals and ecologists provides landscape designers with opportunities to influence green infrastructure decisions. A study by Sörlin (1999) provides evidence that humans perceive landscapes and species as valuable when actors name their values and make these apparent. Landscape designers are potentially influential in this way, as they are leading figures and trend-setters in the green industry in South Africa (Middleton 2012).

In spite of landscape design professionals' potential to influence land use struggles and decisions, in South Africa, currently too little attention is paid to green infrastructure. Landscape designers have to compete with other actors in the process of value articulation (Ernstson 2013). Other built environment professionals and clients have their own established cultural values and objectives, employing artifacts such as reports or laws, and social arenas such as meetings or conferences. Ernstson (2013) and Latour (2005) describe humans coupled with non-humans as actor-networks that construct narratives and powerful explanations of the value of certain considerations that they favor. These actor-networks wield knowledge to a specific purpose, influencing extended networks of decision-making 
(Ernstson 2013; Latour 2005). The debate and struggle over land use practices is thus guided by discourse, power and institutional procedure, and professionals involved in the built environment are in an advantageous position.

\section{The South African scenario}

In South Africa, the terms "green infrastructure" and "ecosystem services" feature increasingly in academia, policy documents and professional magazines, but are seldom employed actively in practice in deliberations on urban land use decisions. As a result, tradeoff choices are typically considered. The value and benefits of decisions about the urban environment are often not objectively measurable (Ernstson 2013:8-12); moreover, instead of a rational best choice resolution, the decision to favor particular ecosystem services is often based entirely on social norms and underlying values; for example, regionally indigenous vegetation may be regarded as insufficiently ornamental or as "untidy" and so the cultural services of aesthetics may overrule habitat creation (a supporting service). The State may want to link development to livelihood and biodiversity protection, even though national and local policies do not always reflect this objective (Dominelli 2012:151). Conversely, marketdriven actions favor the lowest overall cost as the primary deciding factor, irrespective of the needs of people or the environment (Dominelli 2012:135).

The development process in South Africa allows for substantial professional input and initiative from landscape designers. At municipal level, there are a number of main requirements or criteria for private and public development projects that contain "significant landscape components". Design proposals are circulated to several government departments, including some with government-employed landscape designers. According to correspondence with council officials at the Tshwane, Johannesburg, Cape Town and eThekwini municipalities (2014), their requirements entail inter alia the use of mainly 
indigenous species, the priority of public safety, inclusive design, low maintenance requirements, and quantitative aspects such as plant densities per area. The nature of the development may further require community and stakeholder engagement, the employment of local labor and skills development initiatives. The perceived main concern of the various councils is currently to compel professional landscape design input in new development projects, while monitoring “ecosystem disservices” (Lyytimäki and Sipilä 2009), such as social nuisances and financial and environmental costs. Once landscape designers are included in a project, municipal and client requirements are unlikely to hamper their creative pursuit of structural diversity, habitat creation, community involvement and multifunctionality. This is, in our opinion, the crux of the power that landscape designers hold in terms of their professional decisions.

An example is the inclusion of a biodiversity garden in Green Point Park in Cape Town, adjacent to a newly erected sports stadium for the FIFA World Cup held in South Africa in 2010. This was an initiative that originated with the designers and was supported by a council member. Today, this garden attracts schools and other interest groups which visit it for educational and awareness purposes, thanks to the initial endeavors of two people (Van Papendorf 2013, personal communication). This illustrates how a landscape designer can initiate a project for biodiversity awareness and well-being, but the question arises whether this is the norm for the type of concerns addressed in the industry.

\section{Methodology}

Publications such as newspapers, magazines and internet websites are useful sources from which to obtain insight into social opinions and value systems. When the media write about a place or topic, a double process occurs: collective practices are captured and exhibited in the form of values, themes and hierarchies; at the same time, these sources provide a social 
critique. Values are captured in a convenient form that orients, models and represents recognition of a previous or existing social discourse (Aguilar Díaz 1998). In this study, the authors gathered discussions on landscape design projects from the content of three prominent magazines distributed to a range of stakeholders involved in landscape design practice in South Africa. The magazines were identified as important arenas of interaction between the media, the focus area and the profession. This method demonstrates how green infrastructure is related to life and the day-to-day realities in the city, revealing important social themes (Aguilar Díaz 1998).

The three magazines that were selected were Urban Green File, which is aimed at custodians, planners, designers and managers of the urban environment, Landscape SA, which focuses on all green industry-related concerns, and Environmental Management, which concentrates on sustainable development. These profession-focused magazines are well known in the industry and have been previously identified as influential in terms of environmental planning and design (Garner, foreword in Stoffberg et al. 2012). In addition to landscape architects and landscape contractors, the magazines are distributed to government departments and property developers, as well as other built environment professionals - architects, urban designers, engineers, and environmental practitioners. More than ten thousand copies of the three magazines collectively are distributed every two months to the main urban centers throughout South Africa. They are mostly mailed to a selected audience free of charge, or offered at a low cost (US\$3). Two of the three magazines also make some issues available electronically. The magazines examined covered the period from January 2004 to January 2013. It was decided to investigate magazines from 2004 onwards (note that Environmental Management only started up in October 2005), a period characterized by economic variance versus political constancy. In total, 144 magazines were reviewed, that featured 655 main articles and 355 design projects. 
The context analysis used the general categories that would be considered in ecological field studies (McGregor-Fors 2011). The first seven categories listed in Table 1 were used to establish the nature and representativeness of the featured projects, but the last four categories

Table 1 The categories and criteria used for the analysis of the design projects and main articles

\begin{tabular}{|c|c|c|}
\hline Category & Subcategories & Criteria \\
\hline 1. Geographic location & Province and name of settlement area. & Google Earth was used to verify locations in South Africa. \\
\hline 2. Urban location & City (center, suburban); Town; Village; Rural. & $\begin{array}{l}\text { City => } 1 \text { million inhabitants; Town }=<1 \text { million }>20000 ; \\
\text { Village }=<20000 \text { people; Rural }=\text { isolated settlements }(10- \\
20 \mathrm{~km} \text { away from the above })\end{array}$ \\
\hline 3. Vegetation type & $\begin{array}{l}\text { Albany Thicket; Dessert; Grassland; Indian } \\
\text { Ocean Coastal Belt; Forest; Fynbos; Nama } \\
\text { Karroo; Savannah; Succulent Karroo. }\end{array}$ & $\begin{array}{l}\text { Vegetation type based on biomes (Mucina and Rutherford } \\
\text { 2006). }\end{array}$ \\
\hline 4. Design type & $\begin{array}{l}\text { Engineering; Architecture; Landscape; Urban } \\
\text { Design. }\end{array}$ & Type of design intervention. \\
\hline 5. Human use & $\begin{array}{l}\text { Residential; Retail: office; Retail: } \\
\text { accommodation; Recreation; Mixed use; } \\
\text { Infrastructure; Commercial; Industrial; } \\
\text { Institutional; Conservation. }\end{array}$ & $\begin{array}{l}\text { Type of economic development (Farinha-Marques et al. } \\
\text { 2011). }\end{array}$ \\
\hline 6. Owner & Private developer or state-owned. & \\
\hline 7. Access & Private; Public; or Restricted access. & Open; Fenced; Boom gate; Guarded or the like. \\
\hline 8. Site character & $\begin{array}{l}\text { High; Medium; or Sparse level of development } \\
\text { (McGregor-Fors 2011). }\end{array}$ & $\begin{array}{l}\% \text { of built up area: } 100-67 \% ; 66-34 \% ; 33-0 \% \text { (McGregor- } \\
\text { Fors 2011). }\end{array}$ \\
\hline 9. Land cover & $\begin{array}{l}\text { Physical surface characteristics (Werner and } \\
\text { Zahner 2010). }\end{array}$ & $\%$ of disturbed vegetation (McGregor-Fors 2011). \\
\hline 10. Ecological scale & $\begin{array}{l}\text { Patch; matrix; landscape (Werner and Zahner } \\
\text { 2010). }\end{array}$ & $\begin{array}{l}\text { One land use type; city-wide; into urbanized surrounds } \\
\text { (Werner and Zahner 2010) }\end{array}$ \\
\hline $\begin{array}{l}\text { 11. Infrastructure } \\
\text { character }\end{array}$ & $\begin{array}{l}\text { Grey; Green; Blue; Brown (Farinha-Marques } \\
\text { et al. 2011). }\end{array}$ & $\begin{array}{l}\text { Sealed surface; Green; Water; Reused land (Farinha-Marques } \\
\text { et al. 2011). }\end{array}$ \\
\hline
\end{tabular}

Source: Authors (2014)

(8 to 11) could not be established in all cases. This part of the analysis for each article provided contextual background for the thematic interpretation that followed. 
Swaffield (2013:1194) explains that values frame the landscape design process and decisions, and are materialized in design outcomes. The primary classification of the text was based on the topic(s) of value featured in each main article and embodied in the landscape design projects under discussion. A combination of content and thematic analysis (Namey et al. 2007) was done to quantify the relative frequency of topics or themes in the data set and to identify trends over time. Theme frequency was assessed rather than word frequency to incorporate context into the analysis, as recommended by Namey et al. (2007:143). The first approximation focused on observing and identifying words that expressed the main themes of the articles. The title, subtitles, images and text of the articles were interpreted to deduce the primary subject matter(s) or value projection(s). A phenomenological data-driven approach was taken, in that themes were noted as they occurred and were not predetermined. These topics were then grouped through their association with the four main categories of ecosystem services, namely cultural, provisioning, regulating and supporting services, based on the description of the MEA (2005), and the division of the categories according to the example provided by TEEB (2011). In this way, the ecosystem service(s) represented by the nature and function of the design project was(were) identified for each main article.

The aim of the analysis was to reveal the construction of values vis-à-vis urban nature as related to cultural material and text (Terre Blanche et al. 1999) in the landscape industry. The limitation of the method employed lies in the possibility of a strong bias among the editors with regard to their criteria for the selection of material, which may differ from those of landscape designers at large. However, it may be argued that editors and marketing agents strive to achieve buy-in from their readers - most of whom are practitioners in this industry hence, it was assumed that the magazines provide a representative perspective of the generally pertinent concerns and related values in landscape design. 
The research method is transparent and indicative of the raw data that is stable and can be studied in detail; however, the thematic coding does imply interpretation by the analyst, raising questions of reliability (Namey et al. 2007). For this study, the authors attempted to ensure consistency by having only one researcher, who has prior experience in qualitative research methods, interpret all data over a short period of one month. A challenge during the thematic coding of some projects was to consciously distinguish between the grey and the green infrastructure value projections. The authors used the concept of ecosystem services to relate the findings to current scientific discourse (Ernstson 2013). Ecosystem disservices (Lyytimäki and Sipilä 2009) were not overtly articulated in any of the articles, yet the influence of disservices (such as trees interfering with CCTV cameras' views) on norms and values is undeniable.

\section{Results and Discussion}

\section{Representativeness of the results}

The first estimation of the analysis was designed to confirm whether the design projects covered by the magazines contextually matched the criteria of the study. The combined findings indicated that the featured design projects were geographically representative for the whole of South Africa. The three main urban centers represented were situated in the provinces of Gauteng (55\%), the Western Cape (27\%) and KwaZulu Natal (8\%) (n=655). A total of $68 \%(n=355)$ of the featured projects were located in cities. Although the investigation focused mainly on urban issues, all articles were considered - even those that pertained to rural areas (14\%), because urban ecosystems are considered to include adjoining sparsely-populated areas (Pickett et al. 2011). The focus was on landscape design (55\% of the projects), but designs by related professions - architecture, engineering and urban design were also included in the analysis because they revealed values held towards green 
infrastructure practices. Landscape design projects accessible to the public amounted to $45 \%$ $(n=355)$; the remainder of the projects were private properties with gated entries, which was also reflected in the $60 \%$ private (as opposed to State) development. A total of ten different uses were distinguished, most projects being either recreational or large scale residential projects, followed by office retail, infrastructure and commercial projects, in that order. The data demonstrated that the reviewed projects provided a balanced representation regarding landscape design practice, considering location, access, developer and type of design.

\section{Theme and ecosystem service findings}

The main objective of the review was theory-driven in the sense that it aimed to establish base values held regarding urban nature. As Goulder and Kennedy (1997:23) explain, "[s]ociety cannot escape the value issue: whenever societies choose among alternative uses of nature, they indicate (at least implicitly) which alternative is deemed to be worth more". A balance between consistency and open flexibility was pursued in the analysis (Namey et al. 2007). The thematic analysis was therefore also data-driven in that themes (or values) identified in similar studies were not used a priori (e.g. Delavari-Edalat and Abdi 2010; Van Riper et al. 2012). In total, 26 different topics of discussion around green infrastructure were identified. Many articles articulated more than one topic. Each time a topic was identified, it was assigned a full value in terms of frequency measure.

The 11 most frequently articulated topics are displayed in Fig. 2. The first topic was social concerns related to the community, the everyday socio-economic well-being of people, and how landscape design projects addressed these $(14 \%, \mathrm{n}=1228)$. In second place was the goal of sustainability, describing ways in which resources and energy are saved through built 


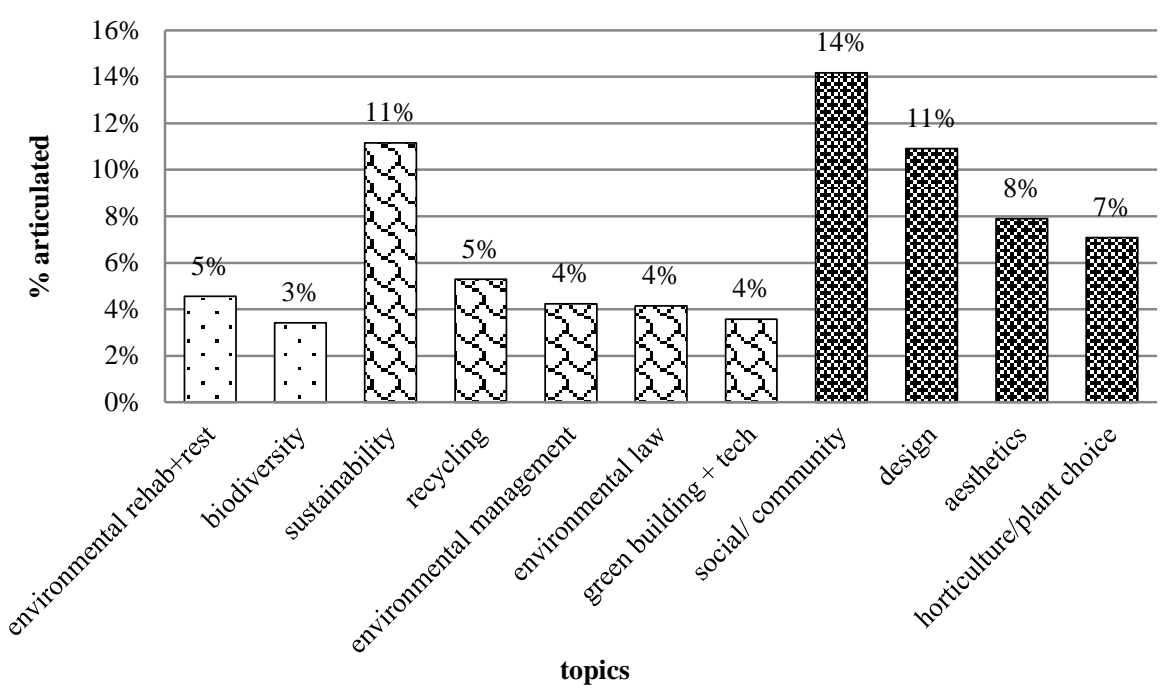

\_supporting services_/ I__regulating services__ / \_cultural services__ I

Fig. 2 The 11 most recurrent topics of concern out of 26, and the percentage of articulations in feature articles (Authors, 2014).

Note: $n=1228$; feature articles often articulated more than one concern/topic, the ' $n$ ' value reflects the total number of topics. A full value was assigned every time a topic occurred, irrespective of the number of topics identified per article.

environment design initiatives. Many articles did not consider it necessary to comment on much other than the design itself and the aesthetic elements of the design. Design as a science and an art form thus came in third place, closely followed in fourth place by the aspiration towards aesthetics. Horticulture and plant choice was the fifth most mentioned topic of concern, and different cultural norms were used as a rationale for plant selection. Of particular interest for the study was environmental restoration and rehabilitation, which came in seventh (5\%), although biodiversity only took eleventh place, at 3\%.

These topics were grouped with one or more of the four ecosystem service categories (MEA 2005; TEEB 2011) with which they were associated. A summary of all the topics matched with each of the ecosystem service types is presented in Fig. 3. A comparison of the 


\section{Cultural Services}

Social/ community (tourism, safety etc); Design; Aesthetics; Horticulture/ plant choice; Education; Urban renewal; Heritage; Identity; Sense of place;

\section{Provisioning services}

Urban agriculture/ permaculture; Medicinal plants;

\section{Regulating services}

Sustainability; Recycling; Green

building/ technology; Law/

environmental control; Environmental

management; Resource management;

Waste; Water wise; Pollution

management; Mining rehabilitation

Climate change; Renewable ennergy;

\section{Supporting services}

Environmental restoration/ rehabilitation; Biodiversity; Habitat;

Fig. 3 The four types of ecosystem services with the total identified 26 topics of concern associated with each service, and ranked by frequency (Authors, 2014).

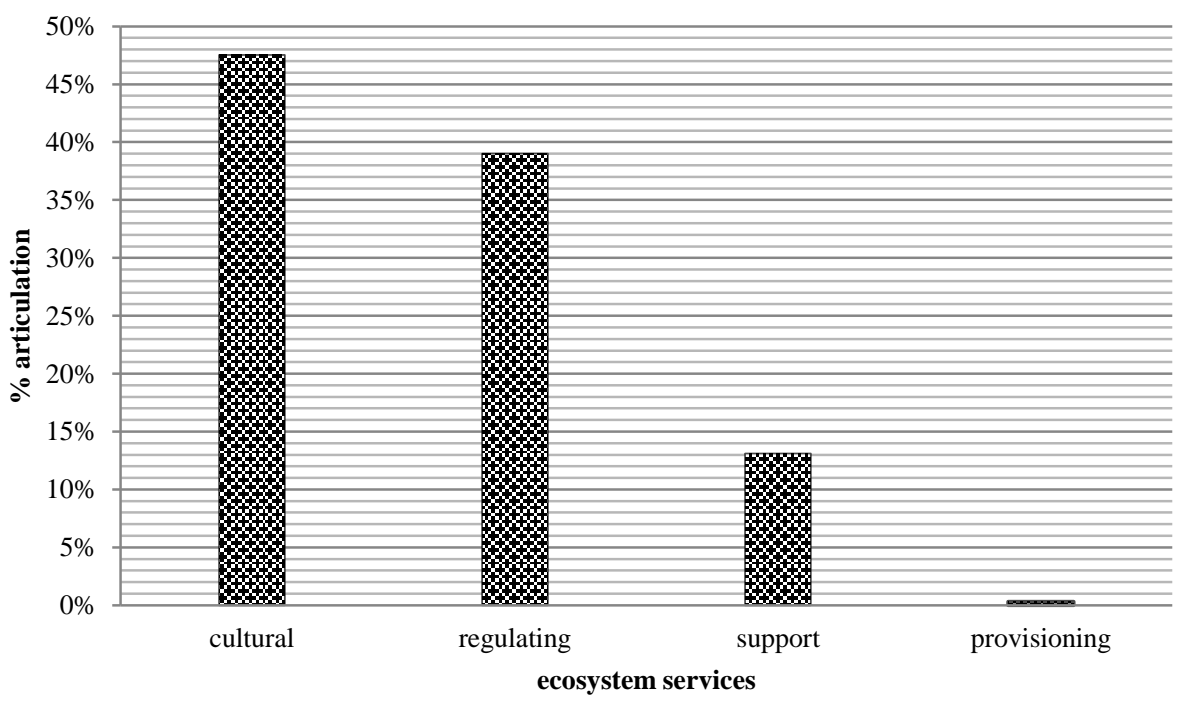

Fig. 4 The four types of ecosystem services and the percentage of articulation in topics of concern (Authors, 2014).

representativeness of the four types of ecosystem services is shown in Fig. 4. The study indicates that $47.5 \%(n=915)$ of the articles articulated primarily the importance of cultural services, and $39.0 \%$ that of regulating services. This contrasts dramatically with a telling lack 
of emphasis on supporting services, at $13.1 \%$, through green infrastructure, and provisioning services, at $0.3 \%$.

\section{Discussion of ecosystem service findings}

The findings reveal a clear imbalance between the way cultural and regulating ecosystem services are valued, as opposed to provisioning and supporting services. Provisioning services are generally appreciated more in developing or rural areas, where people depend directly on nature for food, firewood, water, and construction material. In Africa, these often collectively owned services are also gathered and sold to supplement household income (Egoh et al. 2012:72). However, as people move to city environments, these services are often not available to them any longer, and people's direct dependence on nature is lost. Even the layout of the home gardens of some ethnic groups in South Africa may change radically (with more cultural and fewer provisioning services) as people become more Westernized and move to cities (Molebatsi et al. 2010). In large cities, most of the provisioning services, such as water and food are outsourced beyond the city boundary (O'Farrell et al. 2012). This may partially explain the findings of the study, since the majority of the projects reviewed were urban. A lack of knowledge and the required revision of municipal bylaws to facilitate utility and community gardens are possibly further reasons. Given that $20 \%$ of South African households have inadequate access to food and only $20.7 \%$ actually produce food (DAFF 2010), food gardens can supplement household income (Egoh et al. 2012) and help to reduce vulnerability. Such practices, as part of multifunctional spaces, also have the power to reconnect urban dwellers with their interdependence on nature, which can improve public support in dealing with global environmental challenges (Barthel et al. 2010). For example, in urban Stockholm, Barthel et al. (2010:263) found that allotment gardens provided fertile soils, flowers and vegetables, but also services such as pollination and pest control beneficial to the broader urban landscape. They argue that the "stewards of urban green areas, like those 
engaged in allotment gardens, and the social memory that they carry may help counteract further decline of critical ecosystem services" (Barthel et al. 2010:264). Thus they suggest that urban food gardens are central elements of sustainable urban development and form part of urban governance for resilience (Barthel et al. 2013). The analysis revealed that some food and medicinal gardens are installed by landscape designers in South Africa, but the importance of the provisioning services of nature seems to receive a disproportionate lack of attention in the social production process.

With regard to supporting services, it was found that the need to incorporate diversity and habitat into city environments is not perceived as essential in current design practice. Closer inspection of the data revealed that, comparatively, a higher percentage of projects located in rural areas $(51 \%)$ were associated with supporting services, compared to projects located in towns $(22 \%)$ and projects in cities $(16 \%)$. One possible reason for this phenomenon is competition with other social priorities in urban areas, as well as a common misunderstanding that biodiversity has few direct benefits to humans and little relevance to cities (Ahern 2012). However, aspects of stability, functioning and sustainability of ecosystems depend on biodiversity, which reflects the increased functional roles possible in those areas with more species (Tilman 1997). According to Ahern (2012:4), one should also understand urban biodiversity in the context of response diversity, initially described by Elmqvist et al. (2003:488) as "the diversity of responses to environmental change among species that contribute to the same ecosystem function...[and] ....is critical to resilience, particularly during periods of reorganization" following disturbances. Response diversity can, therefore serve as a key resilience capacity building factor in reaction to the effects of climate change (Ahern 2012). The spatially explicit function and services of biodiversity need to be assessed in more definite terms to allow greater weight in design decisions (Ahern 2012). 
In cities, regulating services, although they are not all highly visible or cherished, are generally considered most valuable, as these services need to be supplied in situ (Egoh et al. 2012). A lack of regulating services, such as temperature and storm water regulation, has an immediate effect on human comfort and urban functioning; they are more evident and easier to quantify. The "engineering" approach to green infrastructure in South Africa has possibly increased the awareness of regulating services. Although often substituted by grey infrastructure, design for regulating services is growing due to affordability and sustainability.

Cultural services include recreation and physical health, aesthetics and spiritual benefits (TEEB 2011). The reasons for the large amount of articulation of cultural services in the design projects reviewed can be related to the current socio-economic and historic-political realities that are indirect drivers of change for ecosystem services (MEA 2005). South Africa is only two decades into democracy, and the overall socio-political thrust is focused on greater social equity and transformation. There has also been a large number of design projects related to celebrating a wider heritage and cultural identity since democracy. Another driver was hosting the FIFA World Cup event in 2010, which called for large-scale sporting facilities and fan park developments throughout the country. All these projects contributed in some degree to the articulation of social and cultural services associated with urban nature. While this is rarely considered in studies, countries become increasingly dependent on cultural services during economic development (Molebatsi et al. 2010; Plieninger et al. 2013). The manifestation of cultural services affects the way ecosystems are seen (MEA 2005) and holds potential for multifunctionality in green infrastructure management (Plieninger et al. 2013). 


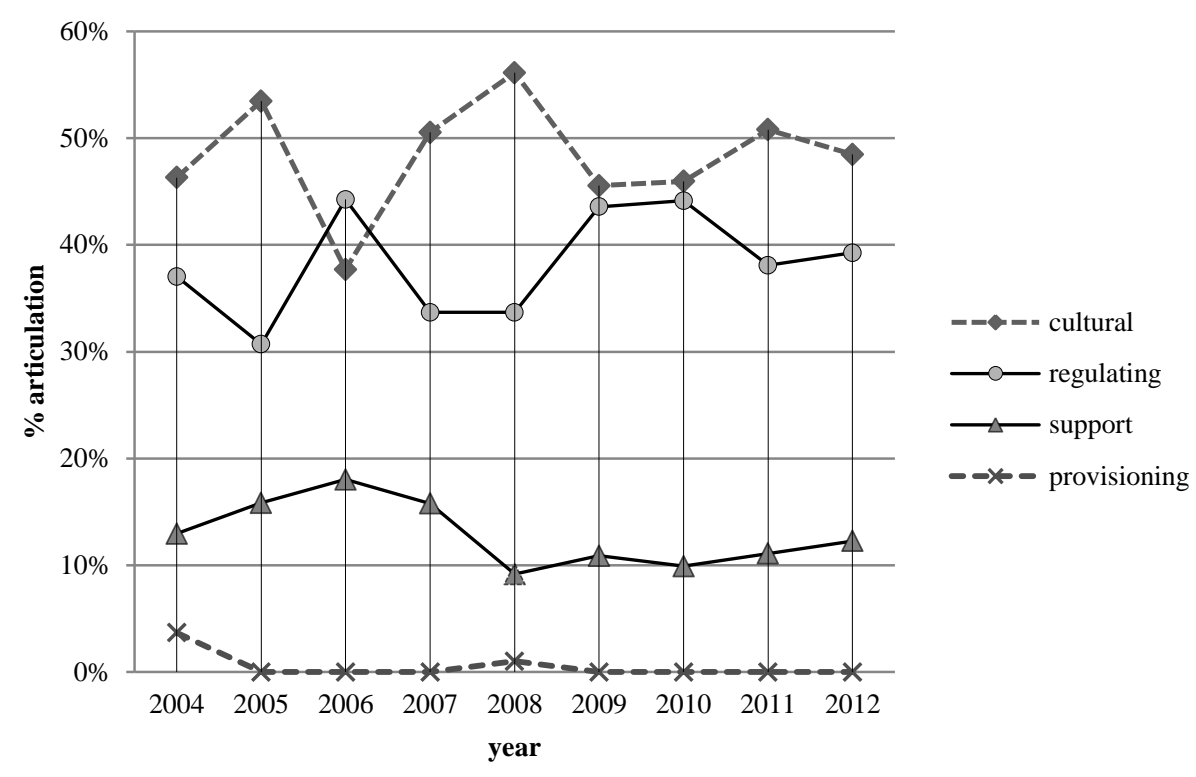

Fig. 5 The percentage articulation of the four types of ecosystem services from Jan. 2004 to Jan. 2013 (Authors, 2014).

No clear changes in tendencies could be identified in the articles analyzed from the nine-year period with regard to ecosystem services articulation. Cultural and regulating services were continuously emphasized more strongly in the articles than supporting and provisioning services, and all the services remained within a ten percent range (see Fig. 5). The focus on cultural versus regulating services seem to be opposed - whenever one increased, the other diminished - which indicates a potential trade-off between them. The dominant articulation of regulating services in 2006 may be a reflection of a period of positive economic growth (that collapsed worldwide in 2008) on professional values. However, it can be concluded that there is a discrepancy between landscape design professionals' perceptions of the importance of ecosystem services and those of researchers, in terms of the relative importance given to ecosystem services. 


\section{Social practices and the reorientation of values}

Our understanding of nature advances with each generation, and the aesthetic design language used to incorporate it into settlements also requires change beyond mere sociocultural and economic trends (Nicholson-Lord 2011:379). This study therefore proposes that values within the profession of landscape design need to be operationalized in order for green infrastructure to reflect a more balanced approach to ecosystem services. Byrne (2011:63) and the authors Byrne cites demonstrate that our interactions with (urban) nature are formative in how we see the world, how we relate to fellow humans and our environment. Kaplan (2011:388) comments: "Both what surrounds us and what is stored in our heads affect our perceptions of subsequent information." This underlines the importance of the existing underlying values this study revealed regarding urban nature in landscape design practice; but also shows the potential that a changing design aesthetic holds: a gradual improvement of public acceptance and understanding of required services as part of urban nature. To increase the value that practitioners assign to provisioning and supporting services, the relation of these services to topics that were deemed important by them (such as social and community affairs, sustainability, design, aesthetics, or horticultural plant choice) can be made more explicit.

The content analysis of the profession-focused magazines used in this study also allowed influential social practices to be identified inside design practice that currently play a role in norms and decision-making among landscape designers. These were rating systems that carry economic incentives; the law, which is related to state authority and prosecution; and awards systems by different institutions based on norms inside the profession. Each of these systems produces artifacts, in terms of actor-network theory (Latour 2005), that can be employed to give weight to arguments around land use. If we consider the potential of these social practices with regard to value change, Mansbridge (1994:147-8) explains that moral or 
altruistic motivation is less susceptible to compromise than punishment or material benefit. For this reason, it can be argued that rating systems that are tied to economic incentives are negotiable as a norm changer (Pretty 2003), while legal incentives fall into the same category, since motivation is extrinsic in the form of punishment. In South Africa, in spite of many good frameworks and policies ( $\mathrm{Du}$ Toit and Cilliers in press), problems surrounding law enforcement and policing are recognized as a matter of concern, which reduces the perceived power of the law. Research has also shown that existing forms of social organization rely on both moral motivation and material sanctions (Mansbridge 1994); for this reason, award systems appear to be the most immediate and practical value promoter. Awards systems can be used to correct misconceptions about ecosystem services and biodiversity, to persuade through public figures such as judges and winners, and to influence learning from comembers with improved environmental training or experience (Aaron et al. 1994). This approach ties in with the proposal of Steg et al. (2014) to strengthen normative goals through value cues and situational factors that influence the accessibility of these values.

According to Mansbridge (1994:148), "[h]uman beings often spend considerable effort making their duty, love and self-interest coincide". The authors are of the opinion that the work of passionate landscape design practitioners in South Africa that put into practice different ecosystem services can provide intrinsic incentives for others. This can lead to the development of "epistemic communities" that evolve consensual knowledge (Haas 1989) and develop the practice on the basis of their shared interests and values. Furthermore, studies show that public spirit can be created through emotions related to a sense of justice, participation in small groups and well-designed deliberation processes that produce a commitment to decisions (Mansbridge 1994:156). The authors suggest that, in this way, award systems, as an agency of shaping institutional and professional knowledge and values, can help to increase recognition of the importance of all ecosystem services and to improve 
green infrastructure. The prospect of reviewing criteria used in local awards systems is currently being explored to be discussed in a future publication.

\section{Conclusion}

Current socio-economic realities and socio-cultural values affect the ability of green infrastructure to support ecosystem services including biodiversity. Decision-making in this field is challenging for designers, as urban nature reflects local values, while the position and influence of various decision-makers are often played off against one another. In South Africa, the role of landscape design practitioners in decision-making has not previously received much attention in research. It is argued that this community of practice is in a central position in respect of its social networks and decision-making capacity to promote the value of green infrastructure. The literature reviewed indicates that all ecosystem services are important for systems resilience, but most of all biodiversity, which is required for the delivery of other services (MEA 2005). In South Africa, the benefits of supporting and provisioning services seem to remain underestimated, while cultural and regulating services are deemed more important. These identified base values in the landscape design industry can serve as important entry points for achieving the required future change in assigned values and decision-making. The study has distinguished a number of different topics that concern the industry and that can serve to relate new assigned values to existing ones namely social and community-related matters, concerns for sustainability, design and aesthetics, and plant choice.

To assist this process, social practices that hold some potential to shape values inside the landscape design industry were considered: environmental laws, ratings systems and award systems. This study proposes using award systems as a social practice with the greatest immediate potential for achieving value change, as they provide intrinsic and extrinsic 
incentives, and can simultaneously foster public spirit and the evolution of consensual knowledge. In this way, landscape designers can play an active role in changing the quality of green infrastructure to provide multiple ecosystem services for improved systems resilience, and (re)connect local users to their dependence on nature.

These findings are also significant for other build environment professions as they highlight the significance of professional values with regard design and planning outcomes. The study distinguishes between public perceptions, social norms and professional values in decision making; it creates awareness of the potential influence of underlying values on assigned values inside a profession which should be further investigated; and it proposes social practices that hold potential to operationalize professional values.

The study calls for the reorientation of values inside the different built environment professions so that the long term societal benefits and losses of various land use scenarios are effectively weighed up in design decisions.

\section{Acknowledgements}

The authors thank the editor of Environmental Management, Carol Knoll, and the editor of Landscape South Africa, Karyn Richards, for supplying us with full sets of their magazines from 2004 to 2013 to review for this study. The authors also thank two anonymous reviewers and the editor in chief for their valuable input.

\section{References}

Aaron, H. J., Mann, T. E., and Taylor, T. eds. (1994). Values and public policy. Brookings Institution, Washington, DC. 
Aguilar Díaz, M. (1998). “Espacio público prensa urbana.” Cultura y Comunicación en la Ciudad de México. La Ciudad y los Ciudadanos Imaginados por los Medios: Segunda parte. N. García Canclini, coord., UAM-I/Grijalbo, México.

Ahern, J. (2012). "Urban landscape sustainability and resilience: The promise and challenges of integrating ecology with urban planning and design.” Landscape Ecol., 28(6), 1203-1212.

Ahern, J., Cilliers, S., and Niemelä, J. (2014). "The concept of ecosystem services in adaptive urban planning and design: A framework for supporting innovation.” Landscape Urban Plan., 125, 254-259.

Alessa, L., Kliskey, A., and Brown, G. (2008). "Social-ecological hotspots mapping: A spatial approach for identifying coupled social-ecological space.” Landscape Urban Plan., 85(1), 27-39.

Barthel, S., Folke, C., and Colding, J. (2010). "Social-ecological memory in urban gardens: Retaining the capacity for management of ecosystem services.” Global Environ Chang., 20(2), 255-265.

Barthel, S., Parker, J., and Ernstson, H. (2013). "Food and green space in cities: A resilience lens on gardens and urban environmental movements. " Urban Stud., 1-18. in press.

<http://www.cityfarmer.org/UrbanBarthel.pdf> (Aug. 15, 2013).

Benedict, M. A., and McMahon, E. T. (2001-5). "Green infrastructure: Smart conservation for the 21st century." Sprawl Watch Clearinghouse, Washington, DC. <http://www.sprawlwatch.org/greeninfrastructure.pdf > (May. 2, 2014).

Bodin, O., and Norberg, J. (2007). “A network approach for analyzing spatially structured populations in fragmented landscape.” Landscape Ecol., 22(1), 31-44.

Box, J. (2011). "Building urban biodiversity through financial incentives, regulations and targets." Urban Ecology: Patterns, processes and applications. J. Niemelä, ed., Oxford University Press, Oxford, UK, 309315.

Byrne, J. (2011). "The human relationship with nature: Rights of animals and plants in the urban context." The Routledge handbook of urban ecology. I. Douglas, D. Goode, M. Houck, and R. Wang, eds., Routledge, London, UK, 63-74.

Chiesura, A., and Martinez-Alier, J. (2011). "How much is urban nature worth? And for whom? Thoughts from ecological economics.” The Routledge handbook of urban ecology. I. Douglas, D. Goode, M. Houck, and R. Wang, eds., Routledge, London, UK, 93-97.

Cilliers, E. J. (2010a). “Rethinking sustainable development: The economic value of green spaces.” M.Sc. thesis, North West University, Potchefstroom, South Africa.

Cilliers, S. S. (2010b). "Social aspects of urban biodiversity - an overview." Urban biodiversity and design. Conservation Science and Practice Series no 7. N. Müller, P. Werner, and J. G. Kelcey, eds., WileyBlackwell, Oxford, UK. 81-100.

Cilliers, S. S., and Bredenkamp, G. J. (2000). "Vegetation of roadside verges on an urbanization gradient in Potchefstroom, South Africa." Landscape Urban Plan., 46(4), 217-239. 
Cilliers, S. S., and Siebert, S. J. (2012). "Urban ecology in Cape Town: South African comparisons and reflections." Ecol. Soc., 17(3): 33.

Cilliers, S.S., Cilliers, J., Lubbe, R., and Siebert, S. (2012). “Ecosystem services of urban green spaces in African countries - perspectives and challenges." Urban Ecosystems, 16(4), 681-702.

Clucas, B., and Marzluff, J. M. (2011). "Coupled relationships between humans and other organisms in urban areas." Urban Ecology: Patterns, processes and applications. J. Niemelä, ed., Oxford University Press, Oxford, UK, 135-147.

Colding, J. (2011). "The role of ecosystem services in contemporary urban planning." Urban Ecology: Patterns, processes and applications. J. Niemelä, ed., Oxford University Press, Oxford, UK, 228-237.

DAFF (Department of Agriculture, Forestry and Fisheries). (2010). "Food security and vulnerability assessment in South Africa". Food Security Information Management Unit. DAFF, Pretoria, South Africa. <www.nda.agric.za/doaDev/sideMenu/foodSecurity/docs/FSandVAsouthAfrica2010.doc>(Nov. 28, 2013).

Delavari-Edalat, F., and Abdi, M. R. (2010). "Human-environment interactions based on biophilia values in an urban context: Case study.” J. Urban Plann. Dev., 136(2), 162-168.

De Wit, M., Van Zyl, H., Crookes, D., Blignaut, J., Jayiya, T., Goiset, V., and Mahumani, B. (2012). "Including the economic value of well-functioning urban ecosystems in financial decisions: Evidence from a process in Cape Town.” Ecosystem Services, 2, 38-44.

Dominelli, L. (2012). Green social work: From environmental crisis to environmental justice. Polity Press, Cambridge, UK.

Douglas, I., and Sadler, J. P. (2011). “Urban wildlife corridors: Conduits for movement or linear habitat?” The Routledge handbook of urban ecology. I. Douglas, D. Goode, M. Houck, and R. Wang, eds., Routledge, London, UK, 274-289.

Douglas, I., Goode, D., Houck, M., and Wang, R., eds. (2011). The Routledge handbook of urban ecology. Routledge, London, UK.

Du Toit, M. J., and Cilliers, S. S. (in press). "Urban ecology in South Africa and its role in local government." South African Environmental Law: The governing function of local government. in press. A. du Plessis, ed., Juta, Cape Town, South Africa.

Egoh, B. N., O’Farrell, P. J., Charef, A., Gurney, L. J., Koellner, T., Abi, H. N., Egoh, M., and Willemen, L. (2012). "An African account of ecosystem service provision: Use, threats and policy options for sustainable livelihoods”. Ecosystem Services, 2, 71-81.

Elmqvist, T., Folke, C., Nyström, M., Peterson, G., Bengtsson, J., Walker, B., and Norberg, J. (2003). "Response diversity, ecosystem change and resilience". Front. Ecol. Environ., 1(9), 488-494.

Ernstson, H. (2012). "Re-translating nature in post-apartheid Cape Town: The material semiotics of people and plants at Bottom Road.” Actor-Network Theory for Development: Working Paper Series. R. Heeks, ed., 
Manchester: Institute for Development Policy and Management, SED, University of Manchester, Manchester, UK.

Ernstson, H. (2013). "The social production of ecosystem services: A framework for studying environmental justice and ecological complexity in urbanized landscapes.” Landscape Urban Plan., 109(1), 7-17.

Ernstson, H., and Sörlin, S. (2009). "Weaving protective stories: Connective practices to articulate holistic values in Stockholm National Urban Park”. Environ. Plann. A, 41(6), 1460-1479.

Ernstson, H., and Sörlin, S. (2013). "Ecosystem services as technology of globalization: On articulating values in urban nature." Ecol. Econ., 86, 274-284.

Ernstson, H., Barthel, S., Andersson, E., and Borgstrom, S. T. (2010). "Scale-crossing brokers and network governance of urban ecosystem services: The case of Stockholm.” Ecol. Soc., 15(4): 28.

Farinha-Marques, P., Lameiras, J. M., Fernandes, C., Silva, S., and Guilherme, F. (2011). "Urban biodiversity: A review of current concepts and contributions to multidisciplinary approaches." Innovation-Abingdon, 24(3), 247-71.

Folke, C. (2006). "Resilience: The emergence of a perspective for social-ecological systems analyses." Global Environ. Chang., 16(3), 253-267.

Folke, C., Carpenter, S.R., Walker, B., Scheffer, M., Chapin, T., and Röckstrom, J. (2010). "Resilience thinking: Integrating resilience, adaptability and transformability.” Ecol. Soc., 15(4):20.

Francis, R. A., and Lorimer, J. (2011). "Urban reconciliation ecology: The potential of living roofs and walls." J. Environ. Manage., 92(6), 1429-1437.

GIW (Green Infrastructure Wiki). (2013). “Glossary: University of Melbourne, Green Infrastructure Research Group.” Definition. <http://www.greeninfrastructurewiki.com/terms> (Oct. 25, 2013).

Gómez, F., Jabaloyes, J., Montero, L., De Vicente, V., and Valcuende, M. (2011). “Green areas, the most significant indicator of the sustainability of cities: Research on their utility for urban planning." J. Urban Plann. Dev., 137(3), 311-328.

Gómez-Baggethun, E., and Barton, D. N. (2013). "Classifying and valuing ecosystem services for urban planning." Ecol. Econ., 86, 235-245.

Goulder, L. H., and Kennedy, D. (1997). "Valuing ecosystem services: Philosophical bases and empirical methods." Nature's services: Societal dependence on natural ecosystems, G. C. Daily, ed., Island Press, Washington, DC, 23-48.

Haas, P. M. (1989). "Do regimes matter? Epistemic communities and Mediterranean pollution control.” Int. Organ., 43(3), 377-403.

Hansen, R., and Pauleit, S. (2014). "From multifunctionality to multiple ecosystem services? A conceptual framework for multifunctionality in green infrastructure planning for urban areas.” Ambio, 43(4), 516-529.

Holmes, P. M., Rebelo, A. G., Dorse, C., and Wood, J. (2012). “Can Cape Town's unique biodiversity be saved? Balancing conservation imperatives and development needs.” Ecol. Soc., 17(2): 28. 
Hostetler, M., Allen, W., and Meurk, C. (2011). “Conserving urban biodiversity? Creating green infrastructure is only the first step.” Landscape Urban Plan., 100(4), 369-371.

Ives, C. D., and Kendal, D. (2014). "The role of social values in the management of ecological systems.” J. Environ. Manage., 144, 67-72.

Kaplan, R. (2011). "Intrinsic and aesthetic values of human nature: A psychological perspective.” The Routledge handbook of urban ecology. I. Douglas, D. Goode, M. Houck, and R. Wang, eds., Routledge, London, UK, 385-394.

Kirnbauer, M., and Baetz, B. (2014). "Prototype decision-support system for designing and costing municipal green infrastructure.” J. Urban Plann. Dev. in press <doi:10.1061/(ASCE)UP.1943-5444.0000191>.

Latour, B. (2005). Reassembling the social: An introduction to Actor-Network Theory. Oxford University Press, Oxford, UK.

Le Maitre, D. C., O’Farrell, P. J., and Reyers, B. (2007). “Ecosystems services in South Africa: A research theme that can engage environmental, economic and social scientists in the development of sustainability science?” S. Afr. J. Sci., 103, Sept./Oct., 367-376.

Lindenmayer, D. B., and Fischer, J. (2006). Habitat fragmentation and landscape change: An ecological and conservation synthesis. Island Press, Washington, DC.

Lubbe, C. S., Siebert, S. J., and Cilliers, S. S. (2011). "Floristic analysis of domestic gardens in the Tlokwe City Municipality, South Africa.” Bothalia, 41(2), 351-361.

Lyytimäki, J., and Sipilä, M. (2009). "Hopping on one leg - the challenge of ecosystem disservices for urban green management.” Urban For. Urban Gree., 8(4), 309-315.

MacGregor-Fors, I. (2011). "Misconceptions or misunderstandings? On the standardization of basic terms and definitions in urban ecology." Landscape Urban Plan., 100(4), 347-349.

MEA (Millennium Ecosystem Assessment). (2005). Ecosystems and human well-being: Multiscale assessments. Island Press, Washington, DC.

Mansbridge, J. (1994). "Public spirit in political systems." Values and public policy. H. J. Aaron, T. E. Mann, and T. Taylor, eds., Brookings Institution, Washington, DC, 146-172.

McConnachie, M. M., and Cowling, R. M. (2013). "On the accuracy of conservation managers' beliefs and if they learn from evidence-based knowledge: A preliminary investigation.” J. Environ. Manage., 128, 7-14.

McConnachie, M. M., and Shackleton, C. M. (2010). "Public green space inequality in small towns in South Africa." Habitat Int., 34(2), 244-248.

McMichael, A., and Scholes, R. (2005).“Linking ecosystem services and human well-being”. Millennium Ecosystem Assessment. Ecosystems and human well-being: Multiscale assessments. Island Press, Washington, DC, 43-60.

Mertz, O., Ravnborg, H. M., Lovei, G. L., Nielsen, I., and Konijnendijk, C. C. (2007). "Ecosystem services and biodiversity in developing countries.” Biodivers. Conserv.,16(10), 2729-2737. 
Middleton, L. (2012). "The determination of selection criteria for the horticultural use of indigenous plants in South Africa." Ph.D. thesis, University of Pretoria, Pretoria, South Africa.

Molebatsi, L. Y., Siebert, S. J., and Cilliers, S. S. (2010). “The Tswana tshimo: A homegarden system of useful plants with a particular layout and function.” Afr. J. Agric. Res., 5(21), 2952-2963.

Mucina, L., and Rutherford, M. C. (2006). The vegetation of South Africa, Lesotho and Swaziland. South African National Biodiversity Institute, Pretoria, South Africa.

Myers, N., Mittermeier, R.A., Mittermeier, C.G., Fonseca, G.A.B., and Kent, J. (2000). "Biodiversity hotspots for conservation priorities." Nature 403, 853-858.

Namey, E., Guest, G., Thairu, L., and Johnson, L. (2007). "Data reduction techniques for large qualitative data sets." Handbook for team-based qualitative research. G. Guest and K.M. MacQueen. eds., Altamira Press, Lanham, MD, 137-162.

Nicholson-Lord, D. (2011). "Intrinsic and aesthetic values of urban nature: A journalist's view from London." The Routledge handbook of urban ecology. I. Douglas, D. Goode, M. Houck, and R. Wang, eds., Routledge, London, UK, 377-385.

O’Farrell, P. J., Anderson, P. M. L., Le Maitre, D. C., and Holmes, P. M. (2012). “Insights and opportunities offered by a rapid ecosystem service assessment in promoting a conservation agenda in an urban biodiversity hotspot.” Ecol. Soc., 17(3): 27.

Pauleit, S., Liu, L., Ahern, J., and Kazmierczak, A. (2011). "Multifunctional green infrastructure planning to promote ecological services in the city." Urban ecology, patterns, processes and applications, J. Niemelä, ed., Oxford University Press, Oxford, UK, 272-285.

Pickett, S. T. A., Cadenasso, M. L., Grove, J. M., Boone, C. G., Groffman, P. M., Irwin, E., Kaushal, S. S., Marshall, V., McGrath, B. P., Nilon, C. H., Pouyat, R. V., Szlavecz, K., Troy, A., and Warren, P. (2011). "Urban ecological systems: Scientific foundations and a decade of progress." J. Environ. Manage., 92(3), $331-362$.

Pinceti, S. (2012). "Nature, urban development and sustainability - What new elements are needed for a more comprehensive understanding?" Cities, 29, 532-537.

Plieninger, T., Dijks, S., Oteros-Rozas, E., and Bieling, C. (2013). “Assessing, mapping, and quantifying cultural ecosystem services at community level”. Land Use Policy, 33, 118-129.

Plieninger, T., Ferranto, S., Huntsinger, L., Kelly, M., and Getz, C. (2012). “Appreciation, use, and management of biodiversity and ecosystem services in California's working landscapes.” Environ. Manage., 50(3), 427-440.

Pretty, J. (2003). “Social capital and the collective management of resources.” Science, 302 (5652), 1912-1914.

Rebelo, A. G., Holmes, P. M., Dorse, C., and Wood, J. (2011). "Impacts of urbanization in a biodiversity hotspot: Conservation challenges in Metropolitan Cape Town.” S. Afr. J. Bot., 77(1), 20-35. 
Roberts, D. C., Boon, R., Croucamp, P., and Mander, M. (2005). "Resource economics as a tool for open space planning in Durban, South Africa." The urban imperative, Urban Outreach Strategies for Protected Areas Agencies. T. Tryzna, ed., California Institute of Public Affairs, Sacramento, CA.

Roberts, D. C., Boon, R., Diederichs, N., Douwes, E., Govender, N., McInnes, A., McLean, C., O’Donoghue, S., and Spires, M. (2011). "Exploring ecosystem-based adaptation in Durban, South Africa: 'learning-bydoing' at the local government coal face.” Environ. Urban., 24(1), 167-195.

Schäffler, A., and Swilling, M., (2012). "Valuing green infrastructure in an urban environment under pressure - the Johannesburg case.” Ecol. Econ., 86, 246-257.

Shwartz, A., Cheval, H., Simon, L., and Julliard, R. (2013). "Virtual garden computer program for use in exploring the elements of biodiversity people want in cities." Conserv. Biol., 27(4), 876-886.

Sörlin, S. (1999). "The articulation of territory: Landscape and the constitution of regional and national identity." Norwegian Journal of Geography, 53(2-3), 103-112.

Steg, L., Bolderdijk, J. W., Keizer, K., and Perlaviciute, G. 2014. “An integrated framework for encouraging pro-environmental behavior: The role of values, situational factors and goals." J. Environ. Psychol., 38, 104-115.

Stoffberg, G. H., Van Rooyen, M. W., Van der Linde, M. J., and Groeneveld, H. T. (2010). “Carbon sequestration estimates of indigenous street trees in the City of Tshwane, South Africa." Urban For. Urban Gree., 9(1), 9-14.

Stoffberg, H., Hindes, C., and Muller, L. (2012). South African landscape architecture: A Compendium. Unisa Press, Pretoria, South Africa.

Swaffield, S. (2013). "Empowering landscape ecology-connecting science to governance through design values." Landscape Ecol., 28, 1193-1201.

Swan, C. M., Pickett, S. T. A., Szlavecz, K., Warren, P., and Willey, K. T. (2011). "Biodiversity and community composition in urban ecosystems: coupled human, spatial and metacommunity process." Urban Ecology: patterns, processes and applications. J. Niemelä, ed. Oxford University Press, Oxford, UK, 179-186.

TEEB (The Economics of Ecosystems and Biodiversity). (2011). "Manual for cities - Ecosystem services in urban management." <www.teebweb.org> (June 10, 2013).

Terre Blanche, M., Durrheim, K., and Kelly, K. (1999). "First steps in qualitative data analysis.” Research in practice: Applied methods for the social sciences. M. Terre Blanche, K. Durrheim, and D. Painter, eds., University of Cape Town Press, Cape Town, South Africa, 320-344.

Thompson, I. H. (1999). Ecology, community, and delight: Sources of values in landscape architecture, Spon Press, New York, NY.

Tilman, D. (1997). "Biodiversity and ecosystem functioning." Nature's services: Societal dependence on natural ecosystems. G. C. Daily, ed., Island Press, Washington, DC, 93-112. 
UN-HABITAT. (2010). “The state of African cities: Governance, inequality and urban land markets.” United Nations Human Settlement Programme, Nairobi, Kenya.

Urgenson, L. S., Prozesky, H. E., and Esler, K. J. (2013). "Stakeholder perceptions of an ecosystem services approach to clearing invasive alien plants on private land.” Ecol. Soc., 18(1): 26.

Van Riper, C. J., Kyle, G. T., Sutton, S. G., Barnes, M., and Sherrouse, B. C. (2012). "Mapping outdoor recreationists' perceived social values for ecosystem services at Hinchinbrook Island National Park, Australia.” Appl. Geogr., 35(1-2), 164-173.

Voigt, A., Kabisch, N., Wurster, D., Haase, D., and Breuste, J. H. (2014). "Structural diversity: A multidimensional approach to assess recreational services in urban parks." Ambio, 43, 480-491.

Werner, P., and Zahner, R. (2010). "Urban patterns and biological diversity: A review." Urban biodiversity and design. N. Müller, P. Werner, and J. G. Kelcey, eds., Wiley-Blackwell, Oxford, UK, 145-173.

Wilson, J. Q. (1994). “Culture, incentives and the underclass.” Values and public policy. H. J. Aaron, T. E. Mann, and T. Taylor, eds., Brookings Institution, Washington, DC, 54-80.

Wright, H. (2011). "Understanding green infrastructure: The development of a contested concept in England.” Local Environment, 16(10), 1003-1019.

Young, R. F. (2011). "Planting the living city.” J. Am. Plann. Assoc., 77(4), 368-381.

Yu, D., Jiang, Y., Kang, M., Tian, Y., and Duan, J. (2011). “Integrated urban land-use planning based on improving ecosystem service: Panyu case, in a typical developed area of China." J. Urban Plann. Dev., 137(4), 448-458.

Zhao, J., Wang, R., Cai, Y., and Luo, P. (2013). “Effects of visual indicators on landscape preferences.” $J$. Urban Plann. Dev., 139(1), 70-78.

Zipperer, W. C., Morse, W. C., and Johnson Gaither, C. (2011). "Linking social and ecological systems." Urban Ecology: Patterns, processes and applications. J. Niemelä, ed. Oxford University Press, Oxford, UK, 298-308. 